\title{
Civil-military Integration Equipment Research and Comparative Manufacturing
}

\author{
J.Q.Zhao, F. LIANG \\ Company of Postgraduate Management, the Academy of Equipment, Beijing, China
}

H.W.Bai

Department of Equipment Acquisition, the Academy of Equipment, Beijing, China

\begin{abstract}
The development of civil-military integration is not only the national strategic deployment, but also the only way to speed up the transformation of the mode of generating combat capabilities. The distribution of resources is the core of civil-military integration development and the key of civil-military integration construction effect. This paper mainly applies comparative advantage theory to analyze the superiority of military enterprises and private enterprises on equipment research and production in order to realize the optimization of resource distribution.
\end{abstract}

KEYWORD: Comparative Advantage; Civil-Military Integration; the Distribution of Resources

\section{INTRODUCTION}

Using the advantage of military industry enterprises and private enterprises and equipment research and production can effectively alleviate civil-military division status, realize the enterprise resources rational allocation and make full use of, finally realizes the civil-military integration. Nowadays, the allocation of resources is the core of the military and civilian integration type development, is affecting the effects of civil-military integration construction. In this paper, by using the theory of comparative advantage in the process of civil-military integration equipment research and production were analyzed, and give a full play to the superiority of the military industrial enterprises and private enterprises resources to break the military and civilian dual factors of structure, realization of civil-military integration optimal allocation of resources, promote the coordinated development of national defense construction and economic construction.

The rest of the paper is organized in the following sequence. In Section 2, the advantages of civilmilitary integration are introduced in detail. In Section 3, the realization of civil-military integration of comparative advantage is studied. Concluding remarks are summarized in the final section.

\section{ANALYSIS OF THE ADVANTAGE OF CIVIL- MILITARY INTEGRATION OF COMPARATIVE}

With the rapid economic development and scientific and technological progress, the comparative advantage between countries not only be done, and in group and group, between enterprises and enterprises have been developing rapidly. An enterprise has more or better factors of production, relative to the other companies will have comparative advantage, and the enterprise with good product structure, the enterprises have comparative advantage. Civil-military integration using comparative advantage refers to the military industrial enterprises and private enterprises in our country based on the interests of national security, military and economic interests of enterprises the best combining site, on its own advantage resources to strengthen cooperation each other, adjust the industrial chain, optimizing the allocation of resources, promote the development of national defense and economic construction and efficient.

\subsection{Comparative advantage theory}

To better understand the comparative advantage, it is necessary to first explain the meaning of absolute advantage. Absolute advantage means if a country production unit quantity of a product compared to other countries use of resources (labor, capital, etc.) absolute less or more efficient, this country has absolute advantage in the production of this kind of product. Absolute advantage is based on the production of absolute cost comparisons. However, the comparative advantage is based on the opportunity cost of production. Comparative advantage is to show if a country is the opportunity cost of production of a product (measured by other 
products) is lower than in other countries the opportunity cost of producing the product, then this country has comparative advantages on the production of this kind of product. The main idea of comparative advantage: even if a country has absolute advantage in the production of each product is not, as long as its a comparative advantage in some industries can trade with other countries to increase benefits, improve the trade benefits ${ }^{[3]}$.

Applying the theory of comparative advantage in between countries to participate in the whole country is beneficial, however the industry division of labor to produce industrial strategy crisis countries at a disadvantage. The civil-military integration by using the theory of comparative advantage for enterprises to participate in is good, is more beneficial for the whole country. Civil-military integration of comparative advantage refers to the equipment research and production of military industrial enterprises and private enterprises based on the interests of national security, military and economic interests of enterprises the best combining site, find enterprise itself through comparison of comparative advantage, on its own advantage resources to strengthen cooperation each other, adjust the industrial chain, optimizing the allocation of resources, promote the development of national defense and economic construction and efficient.

\subsection{Basic content of civil-military integration of comparative advantage}

Listed below a case elaborates the basic contents of civil-military integration comparative advantage theory.

A private enterprises producing $\mathrm{A}$ unit of $\mathrm{A}$ certain type of tank 120 unit of labor, to produce one unit of A certain type of radar 80 unit labor, which are shown in Table 1. Military enterprise B production unit consumption of the tanks 100 units of labor, to produce one unit of the radar 50 units labor consumption, which are shown in Table 1.

Table 1. production unit consumption of different enterprises.

\begin{tabular}{|l|c|c|}
\hline & Tank uint & Radar uint \\
\hline Private enterprises A & 120 & 80 \\
\hline Military enterprise B & 100 & 50 \\
\hline
\end{tabular}

On the analysis of private enterprises and military enterprise B can be found on military enterprise B production tanks and radar has the absolute advantage. On A separate analysis of private enterprises, the opportunity cost of producing one more unit of the tank is 1.50 units of radar, the opportunity cost of producing one more unit of radar is 0.67 units of the tank. A separate analysis of B to military enterprise, the opportunity cost of producing one more unit of the tank is 2.00 units of radar, the opportunity cost of producing one more unit of radar is 0.50 units of the tank. These situations have been illustrated in the following Table 2.

Table 2. Products of different enterprises.

\begin{tabular}{|c|c|c|}
\hline & Tank & Radar \\
\hline private enterprises A & 0.67 & 1.50 \\
\hline Military enterprise B & 0.50 & 2.00 \\
\hline
\end{tabular}

Compared to private enterprises and military enterprise $\mathrm{B}$ the opportunity cost of production of tanks available: $1.50<2.00$, that is, A tank low opportunity cost of production of private enterprises. Therefore, the private enterprises have comparative advantage in the production of tanks, A military enterprise $\mathrm{B}$ have $\mathrm{A}$ comparative advantage in production of radar.

Assume that private enterprises and military enterprise $\mathrm{B}$ production respective comparative advantage of product which is A private enterprise production tanks, military enterprise $\mathrm{B}$ in the production of radar.

Table 3. Comparison of the different enterprises.

\begin{tabular}{|c|c|c|}
\hline & Tank & Radar \\
\hline private enterprises A & +1.00 & -1.50 \\
\hline Military enterprise B & -1.00 & +2.00 \\
\hline Sum & 0 & +0.50 \\
\hline
\end{tabular}

Through these examples show, use the comparative advantage theory in military and civilian integration has very important practical significance. If the military industrial enterprises and private enterprises cost differences, even if one party enterprise (A) of private enterprises in case completely at A disadvantage, can still have comparative advantage products division of labor cooperation with other enterprises, improve the enterprise economic benefit, to ensure that the interests of national security and military interests.

\section{THE REALIZATION OF CIVIL-MILITARY INTEGRATION OF COMPARATIVE ADVANTAGE}

Civil-military integration development countries, as well as strategy, and speed up the transformation the necessary way of fighting capacity generation mode. Out of a military and civilian integration type development path with Chinese characteristics, must play the advantage of military industry enterprises and private enterprises, should not only adhere to the principal position of military industrial enterprises, private enterprises should also actively introduce advantage. 


\subsection{Improve the system of market access}

To ensure that the private enterprises in weapons and equipment research and production with more vigor and creativity, effective play to the role of the advantages of private enterprises, according to classification review, simple and efficient, effective and practical ideas, perfecting the standard market access system, formulate reasonable access mechanism of private enterprises to enter the military market. With good credit, excellent quality, advanced technology and other advantages of private enterprises, can open a green channel for them according to actual condition, on the one hand, the green channel can be efficient quickly introduce advantage of private enterprises, expanding the scope of the military enterprise and private enterprise competition, the advantages between military and civilian resources rational allocation, strengthening the construction of weapons and equipment. Improve the army of the people of the market access system, which can effectively expand the scope of competitive procurement, make full use of flexibly between, between SOEs and private companies the advantages of resources, improves the efficiency of the equipment construction ${ }^{[4]}$.

\subsection{Build the integration information platform}

In guarantee under the premise of national security, we should give full play to local advantages of information resources, set up the military equipment demand information, private enterprises can quickly obtain the required information platform. Only private enterprises after the procurement requirements information, in order to accurately and timely to participate in the activities of the public bidding of the weapons and equipment research and manufacturing, to their own advantage, optimize the allocation of resources, promote the construction of weapons and equipment. In military and civilian integration equipment in the production of scientific research to exert the advantage of military industry enterprises and private enterprises, must to improve the information release system and compatible information platform for security ${ }^{[5]}$.

\subsection{Giving full play to the advantages of private enterprises}

After the implementation of market economy in our country, the private enterprises attach importance to cost cutting expenditure, flexible mechanism, enterprise capital accumulation, swiftly technology rapidly increase and partially technology has been more than a military enterprise. Army general equipment and supporting products from private enterprises to operate flexibly production can relieve both dispersion and low concentration, redundant construction, mechanism of system of private enterprise itself can play a unique advantage, inspire and regulate private enterprise inner vitality and creativity. On the other hand, military enterprise also can undertake military focus funds core ability and core equipment of scientific research and production. Private enterprises play their own advantages in military and civilian general equipment and accessory products of scientific research production, can play a role of competition, to achieve the rational allocation of social resources, increase the overall social welfare, promote the construction of equipment scientific and economic development.

\subsection{Military enterprise development core parts}

To effectively cope with domestic and international security environment, strengthen the national defense construction in our country, the strong support of independent development of defense science, technology and industry. Military enterprise after years of development, equipment research and production, production technology and processes to get improvement, and accumulated a lot of scientific and technological achievements. Military enterprise in our country the rapid development of aviation, aerospace and nuclear industry is in the world, accumulated a large amount of data and research results. However, on the one hand, because of weapons and equipment upgrading and improvement, military special equipment as well as the core parts of scientific research and production cost has increased dramatically. On the other hand, due to special military equipment and core components involved in national security, military secrets, must be strictly confidential. To determine the concentration of military enterprise to funds, manpower, technology for military advantage elements such as special equipment and the core parts of scientific research and production, casting a super weapon, enhance strategic deterrent.

\section{CONCLUSION}

Number figures consecutively in the order in which Civil-military integration development, as well as the strategy, is the internal demand of the development of military enterprises. Civil-military integration process and equipment research and production activities in the construction of national defense building and economic has the important status and role, promote civil-military integration equipment research and manufacturing can effectively use of social resources, accelerate the harmonious development of economic construction and national defense construction. In military and civilian integration development, using the theory of comparative advantage can make full use of military equipment research and manufacturing enterprises 
and private enterprises the advantage of resources, optimize the scientific research and production of the industrial chain, to better promote the development of weapons and equipment in China science, more effectively promote the sustainable economic development in our country.

\section{REFERENCES}

[1] Yao Guang-Ning. State-owned Military Enterprise CivilMilitary Integration Research. Northwestern University. 2008
[2] Li Jie, Li Xiao-Song, Ye Xiao-Rong. Private Enterprises into the Research and Equipment Research and Production Fields. BBS on Military and Civilian Integration Type Development,2013: 313-317

[3] Liu Hong-Li, Gu Qian. Promote Civil-Military Integration Innovation and Development with Comparative Advantage. 2012(11):29-32

[4] Wang Bao-Kun. The Main Methods of Foreign Defense Industry Military and Civilian Integration

[5] Li Wen-qi, Li Fu-sheng, Zhang Ai-Guo. Study on Civilmilitary Integration Equipment Support Force. Journal of the Academy of Equipment Command \& Technology, 2010(04) 